\title{
Novel Organic Fertilisers for Management of Root-Knot Disease of Soybean [Glycine max (L.) Merrill]
}

\author{
Jonathan Jeremiah Atungwu ${ }^{1, *}$, Gold Eremosele Jude ${ }^{1}$, Timothy Ipoola Olabiyi ${ }^{2}$, Samuel \\ Bukola Orisajo $^{3}$
}

\section{(C) Uganda Martyrs University}

\begin{abstract}
Organic farming is currently receiving great impetus in Africa due to its potentials to improve nutrition, income and livelihoods of resource-poor smallholder farmers. Sustainable management of root-knot nematodes in organically grown soybean remain a major challenge in Africa. Greenhouse studies were conducted to evaluate the efficacy of three novel organic fertilisers (sunshine, neem, and IAR \& $\mathrm{T}$ fertilisers) as organic nematicides for control of Meloidogyne incognita $(\mathrm{Mi})$ in a susceptible soybean variety. The organic fertilisers were applied two weeks before planting. All three organic fertilisers were significant $(\mathrm{P}<0.05)$ in reducing $(96-99 \%) \mathrm{Mi}$ nematode populations in soil leading to $86-100 \%$ improvement in soybean grain yield. There were high and positive relationships between plant heights stem girth and yield components. Root gall development on test crop was negatively correlated with plant growth $(\mathrm{r}=-0.47$ to -0.48$)$ and yield $(r=-0.57$ to -0.59$)$.
\end{abstract}

Keywords $\cdot$ Root-knot nematodes $\cdot$ Neem $\cdot$ Soil amendments

\section{Introduction}

Organic agriculture is relative recent in sub-Saharan Africa, but awareness of and the demand for organic produce has increased tremendously in the last two decades due to its potential to improve nutrition, income and livelihoods of smallholder farmers (Atungwu et al., 2009a). The guaranteed premium prices of organic food and sustainability of organic agro ecosystem have continued to stimulate the interest of more people on the continent to grow and eat organic food.

However, pests and diseases including plant-parasitic nematodes pose great crop production constraints during the early years of conversion to and/or establishment of organic farms. Atungwu et al. (2009b) noted that Nigeria is the leading soybean producer

\footnotetext{
${ }^{1}$ University of Agriculture. *Corresponding author: atungwujj@unaab.edu.ng 2 Ladoke Akintola Univeristy of Technology

3 Cocoa Research Institute of Nigeria
} 
in Africa. However, organic soybean production is seriously threatened by pests because organic standards do not permit the use of synthetic chemicals for pest control. The southern root-knot nematodes, $M$. incognita are well documented as a major limiting factor in soybean production in Nigeria (Adesiyan et al., 1990; Ihekwuemere, et al., 1996; Atungwu and Kehinde, 2008). Grain yield losses of up to $87 \%$ have been reported in nematode susceptible soybean grown in Nigeria's arable soils (Afolami and Atungwu, 2001). Organic soybean production excludes the use of synthetic nematicides which are often dangerous to both targeted and non-targeted and often beneficial organisms in the soil.

Therefore, to profitably grow soybean organically there is a need for development of acceptable, affordable and sustainable means of controlling the southern root-knot nematodes, $M$. incognita currently ravaging agricultural soils in Nigeria. Advocacy for organic farming in the country has led to the development of commercially available organic-based fertilisers by Government agencies and private organisations. These products which are often 350 - $500 \%$ lower in prices compared to inorganic fertilisers are currently undergoing nation-wide trials for crop yield performance. Evaluating them for grain yield production alone may not sufficiently document the potential role of these novel organic inputs in curbing the incursion of Mi in organic soybean fields. . Although, Egunjobi (1992) recommended farmyard manure as effective nematicides for farmers in Nigeria, un-cured manure is not acceptable in organic farming, hence, the need to compost or process into organic fertilisers. Therefore, efforts of fertiliser companies to provide readily available and acceptable organic fertilisers warranted this study.

Up to $93 \%$ inhibition of nematode reproduction has been reported resulting in 10 times higher soybean grain yield in soil amended with organic materials (Atungwu and Lawal, 2008; Atungwu et al., 2009). Atungwu and Lawal (2008) tested an organic based fertiliser developed by the Institute for Agricultural Research and Training (IAR \& T) at Ibadan in Nigeria and achieved considerable reduction in Mi nematodes in soybean. Atungwu et al. (2009) also noted that neem product applied singly or in combination with the IAR \& T organic fertiliser was equally efficient in inhibiting nematode reproduction in $\mathrm{Mi}$ susceptible soybean. Atungwu and Kehinde (2008) earlier concluded that the combination was comparable with a synthetic nematicide, Furadan $3 \mathrm{G}$ in reducing $\mathrm{Mi}$ nematode population in TGx 1019-2EN soybean. In fact, according to these authors, organic fertiliser boosted soybean grain yield of the soybean over and above Furadan-treated plants. These levels of efficacy of organic materials against nematodes have compelled nematologists to evaluate the various organic fertilisers in the country for relative effectiveness. The objective of this study was to determine the efficacy of three novel organic based fertiliser formulations for control of Meloidogyne incognita for soybean production in Nigeria.

\section{Materials and Methods}

A screen house experiment was conducted in 2008, and repeated in 2009 at the University of Agriculture, Abeokuta, Nigeria. Three novel organic fertilisers were used namely, Sunshine organic fertiliser, Neem fertiliser, and IAR \& T fertilizer. They were applied in soil in quantities of $40 \mathrm{~g}$ each per $4 \mathrm{~kg}$ of sandy loam topsoil which had been heatsterilised at $65^{\circ} \mathrm{C}$ for $1.5 \mathrm{hr}$. Overall; $4 \mathrm{~kg}$ of soil were used per 6-litre pot. The soil was homogeneously mixed with $1 \% \mathrm{w} / \mathrm{w}$ of each of the organic fertiliser 14 days prior to 
planting. Pots that received no organic fertiliser served as control. The bottoms of the pots were perforated to allow drainage of excess water during daily watering. Physiochemical properties of the soils were determined (Table 1) using routine methods such as flame photometer and Kjeldahl analytical procedure. Soybean variety, TGx1019-2EN was the study crop and seeds were sourced from the International Institute for Tropical Agriculture (IITA) at Ibadan in Nigeria. Proximate compositions of the organic fertilisers are presented in Table 2. Treatments include:

a) Control: TGx 1019-2EN inoculated with Meloidogyne incognita + no fertiliser ;

b) TGx 1019-2EN inoculated with Meloidogyne incognita + sunshine fertiliser ;

c) TGx 1019-2EN inoculated with Meloidogyne incognita + IAR\& T fertiliser; and

d) TGx 1019-2EN inoculated with Meloidogyne incognita + neem fertiliser .

Treatments were laid out in completely randomised design with six replications. The seeded pots were watered daily. Each pot was made to support one soybean plant

\section{Inoculation of Soybean Seedlings}

Pure culture of $M$. incognita previously maintained on susceptible Celosia argentea variety, TLV 8 obtained from the National Horticultural Research Institute at Ibadan in Nigeria, was used for inoculating soybean seedlings. Eggs were extracted from eight weeks old highly galled $C$. argentea roots, using $0.52 \%$ active ingredient (a.i.) sodium hypochlorite $(\mathrm{NaOCl})$ method (Hussey and Barker, 1973). During extraction, washed galled roots of $C$. argentea were cut into $1-2 \mathrm{~cm}$ pieces and placed in a $200 \mathrm{ml}$ of $0.52 \%$ a.i $\mathrm{NaOCl}$ at the ratio of 1:3 in a $500 \mathrm{ml}$ capacity conical flask. Then it was tightly corked and shaken manually but vigorously for three minutes to dissolve the gelatinous matrix enclosing the egg masses. The suspension containing the eggs was quickly poured over a 200-mesh sieve, sandwiched upon a 500-mesh sieve in which the eggs were caught. The 500- mesh sieve containing the eggs was quickly placed under a gentle stream of cool tap water to rinse off residual of $\mathrm{NaOCl}$. The rinsed $M$. incognita eggs were poured into a beaker after rinsing the 500-mesh sieve. Egg suspension was adjusted to $400 \mathrm{ml}$ and calibrated by pipetting out $1 \mathrm{ml}$ aliquot into a Doncaster (1962) ringed counting dish and the eggs were estimated under a stereomicroscope in the laboratory.

Each seedling was inoculated with 5,000 eggs of the nematode, one week after emergence. Inoculation was done by pouring suspension containing 5,000 eggs of $M$. incognita into a shallow circular trench around the base of the seedling (Iheukwumere et al., 1995). The trench was covered with small quantity of the topsoil after which it was wet lightly and daily afterwards.

\section{Data Collection and Analysis}

Data were obtained on plant height, stem girth and number of branches at 4 and 8 weeks after inoculation. Sixty days after inoculation, destructive plant sampling was done in 3 out of the 6 replicates per treatment to determine the number of galls and to estimate nematode reproduction ability. To achieve this, $M$. incognita eggs were extracted from soybean roots using Hussey and Barker (1973) sodium hypochlorite (1\%) method earlier described. Adult nematodes were extracted from the soil using Whitehead and Hemming (1965) method. The summation of the nematode eggs and adults produced the final nematode population, which was divided by the initial 5,000 egg population to estimate the reproduction potentials of the nematode. 
Data collected were subjected to analysis of variance (ANOVA) using SAS (2000) software. Significantly different treatment means were separated using Fisher's Least Significant Difference $\left(\mathrm{LSD}_{0.05}\right)$.

\section{Results}

Data for the effect of the study of organic fertilisers on key growth parameters of soybean grown in $M$. incognita infested soil are presented in Table 3. All the organic fertilisers had statistically significant $(\mathrm{P}<0.05)$ positive influences on the growth and stem girths of soybean plants. Plant height ranged from 47.74 to $66.90 \mathrm{~cm}$ in fertiliser-treated plants at four weeks after inoculation (WAI), to 85.98 to $103.00 \mathrm{~cm} 8 \mathrm{WAI}$ in 2008. These growth responses were significantly $(\mathrm{P}<0.05)$ higher than their control counterparts. Similar responses were observed for stem girth in the fertiliser-treated plots (Table 3). Results obtained in 2008 were consistently parallel with those of 2009

The positive impacts of the fertilisers on growth of soybean plants, in spite of the initial aggressive $\mathrm{Mi}$ populations and the susceptibility status of TGx 1019-2EN soybean varieties was linked to the nematicidal effect of the fertilizers. In 2008, it was clearly shown that Mi population was effectively suppressed in the soybean roots and in the soil as a result of organic fertiliser application. Final population of Mi recovered from each plot varied significantly from fertiliser-treated plants to the control. Neem fertiliser gave the highest observed suppressive effect $(99 \%)$ on Mi population followed by IAR \& T (98 $\%)$, and sunshine fertilisers $(96 \%)$ which were all similar but statistically $(\mathrm{p}=0.05)$ different from the control treatment. Reduced Mi populations in the rhizosphere of the soybean plants significantly $(\mathrm{p}=0.05)$ lowered the severity of the root-knot disease from 86 galls per plant in control treatment to $1-5$ galls per plant observed in roots of organic fertiliser-treated TGx 1019 soybean variety. This means that the fertilisers tested in this experiment suppressed root-knot disease by $94-99 \%$. Neem gave the highest reduction in Mi nematode population and it subsequent damage on the soybean plants evaluated. The 2008 results were in concurrence with the 2010 observations.

The role played by the three organic fertilisers in suppressing southern root-knot nematode $M$. incognita population vis-à-vis reduction in plant damage by the invading nematodes could be directly linked to the marked increases in yield and yield components (Table 5) of the inoculated soybean plants grown in organic fertiliser-amended soil. Number of branches, pods and seeds per soybean plant varied significantly $(\mathrm{p}=0.05)$ between amended soil and their control counterparts both in 2008 and 2010 experiments. There were $77-86 \%, 64-71 \%, 90-106 \%$ and $86-100 \%$ higher pods, seeds, pod weight and seed weight per plant respectively in soybeans plants that received organic fertiliser application compared to untreated plants observed in 2008. Similar results were documented when the experiment was repeated in 2010. These statistics follow the same pattern observed by previous findings (Atungwu and Lawal, 2008; Atungwu and Kehinde, 2008, Atungwu et al., 2009b). Correlation studies presented on Table 6 relates some soybean growth indices with root galling and Mi infection indices. Correlation coefficients (r) were generally negative but insignificant between root galls and plant height and stem girths irrespective of the year of the experiment was conducted. This implied that gall initiation was sufficiently inhibited to such an extent that less root-knot disease severity was observed which did not warrant stunted growth that is usually characteristic of TGx 1019-2EN being an Mi-susceptible soybean variety. Consequently, the relationship 
between root gall and seed production was positive and significant in $2008(\mathrm{r}=0.59)$ and $2010(\mathrm{r}=0.57)$.

\section{Discussion}

Soil amendment with different types of organic fertilisers caused significant reduction in populations of root-knot nematodes and their damage thus resulting in enhanced tolerance to $\mathrm{Mi}$ and subsequent improved yields of the soybean. This finding is in agreement with several previous workers' reports (Kaplan and Noe, 1993; Sharma et al., 1997; Verma et al., 1997; D’Addabbo et al., 2000). Akhtar and Mahmood (1986) and Rodriguez-Kabana (1986) found that organic amendment with composted manure, oil cast of neem (Azadirachta indica), and castor (Ricinus cummunis) were potent in reducing populations of phytonematodes due to their low $\mathrm{C}: \mathrm{N}$ ratio (6-10) and high ammonium nitrogen content. Our findings in this present work particularly in neem fertiliser-treated plots showed significant reduction of the in the number of $M$. incognita (Mi) eggs/infective stage juveniles, qualitative root damage referred to as galls, soil nematode populations and the reproducibility of the invading nematodes in the roots of the Mi-susceptible soybean variety tested. This is probably due to the action of the active ingredient Azadirachtin as reported in neem products studied by Atungwu et al. (2009b). Similar impacts were observed in the two other organic fertilisers evaluated even though their efficacies on nematode survival and reproduction were numerically lower than in the neem fertilisertreated plants, they generally exhibited significant control potentials on the population and reproduction ability of Mi in the present study. This substantiates Atungwu (2006) report that organic materials such as soil amendments have the potentials for suppressing plantparasitic nematodes populations in the soil thus can improve growth and yield performance of Mi-susceptible host plants. It also bears some credence to Engunjobi's (1992) report that organic materials are effective nematicides for farmers in Nigeria.

Positive correlation between root gall and seed production observed in this study implied that organic fertiliser application conferred on TGx 1019 - 2EN the status of Mitolerance as against its actual designation as susceptible variety (Afolami and Atungwu, 2001). It goes to show that resistance/tolerance may be reasonably boosted through application of organic nematicide. Enhancement of tolerance/resistance of crop varieties through organic soil amendment is being investigated.

\section{Conclusion}

It has been clearly shown that organic farming would play a significant role in the management of nematode pests of arable crops. Organic fertilisers are effective nematicides that are ecologically acceptable and farmer friendly low cost production inputs and should be encouraged in the emerging organic sector in Nigeria and other African nations. This has positive implications for sustainable development on the African continent. 


\section{Acknowledgements}

The Authors are grateful to the IITA and IAR \& T both at Ibadan, Nigeria as well as Ondo State Government for the provision of seeds and organic fertilisers used for the study. Faith Atungwu is fondly acknowledged for typesetting the manuscripts freely.

\section{References}

Adesiyan, S. O., Caveness, F. E.. Adeniji, M. O., and Fawole, B. 1990. Nematode Pests of Tropical Crops. Heinemann Educational Books (Nig.) Ltd. pp 113.

Afolami, S. O. and Atungwu, J. J. 2001. Reaction of four varieties of soybean, Glycine max (L.) Merr to infection by Meloidogyne incognita (Kofoid and White) Chitwood race 2. Tropical Oilseeds Journal 5: 1 - 9.

Akhtar, M. and Mahmood, I. 1996. Control of plant-parasitic nematodes with organic and inorganic amendments in agricure soil. Applied Soil Ecology 43:243 -247.

Akhtar, M. and Mahmood, I. 1986. Control of plant-parasitic nematodes with organic and inorganic amendments in agricultural soils. Applied Soil Ecology 43: $243-247$

Atungwu J. J. 2006. An overview of the impact of organic manure as plant-parasitic nematode suppressant. An Appraisal. In: Proceedings of the $1^{\text {st }}$ National Conference of the Organic Agriculture Project in Tertiary Institutions in Nigeria. F.O. Olasantan, I. O. O. Aiyelaagbe, V. I. O. Olowe, B. B. Philip, and O. A. Babalola (Eds.) 149 - 157.

Atungwu, J. J. and Lawal, M. O. (2008): Efficacy of organic based fertiliser in the management of Meloidogyne incognita in soybean. An Appraisal Proceedings of the $1^{\text {st }}$ West African Summit and $4^{\text {th }}$ National Conference on Organic Agriculture. I. O. O. Aiyelaagbe, Adetunji, M. T. and Osei, S. A (Eds.) $130-132$.

Atungwu, J. J. and Kehinde, L. O. (2008): Evaluation of organic based fertiliser as an alternative to Furadan in the management of Meloidogyne incognita on soybeans in Nigeria. International Journal of Nematology. 18 (1): 61 - 65.

Atungwu, J. J., Aiyelaagbe, I. O. O., Sobowale, P. A. S., Oni, A. O. and Sharubutu, S. H. (2009a): Integrating African traditional farming and organic agriculture. In Proceedings of the $5^{\text {th }}$ National Conference of the Organic Agriculture Project in Tertiary Institutions in Nigeria (OAPTIN). Obiefuna, J. C., A. B. I, Udedibie, G. E. Osuji, M. C. Ofoh, D. I. Osuigwe, E. U. Onweremadu and E. B. Etuk (Eds.), $280-283$.

Atungwu, J. J., Ademola, A. A. and Aiyelaagbe, I. O. O. (2009b): Evaluation of organic materials for inhibition of nematode reproduction in soybean. African Crop Science Journal, 17 (4): 167 - 173.

Caveness, F. E. 1992. Nematological Research at the International Institute of Tropical Agriculture, Ibadan. A summary of investigation conducted between 1969 and 1988. Ed. J. Lowe. Plant Health Management Research Monograph

D'Addabbo, T., Sasanelli, N., Lamberti, F., and Carella, A. 2000. Control of root-knot nematodes by olive and grape oil pomace soil amendments. In: Gullino, M. L., Katan, J., and Matta, A. (eds.) Proceedings of the fifth International Symposium on Chemical and Non Chemical Soil and Substrate disinfestations. Acta Horticulturae 523: 53 - 55

Doncaster, C. C. 1962. A counting dish for nematodes. Nematologica 7: 334 - 336.

Egunjobi, A. O. 1992. The place of cultural control strategies in the management of 
nematode problems of food crop in Africa. In: The Biology and Control of Nematode Pests of Food Crops in Africa. Proceedings of the First Regional Symposium on the Biology and Control of Nematode Pests of Food Crops in Africa. Pp 155 - 173

Hussey, R. S. and K. R. Barker. 1973. A comparison of methods of collecting inocula for Meloidogyne spp., including a new technique. Plant Disease Reporter 57: 1025 1028.

Iheukwumere, C. C., Atiri, G. I., Fawole, B., and Dashiell, K. E. 1995. Evaluation of some commonly grown soybean cultivars for resistance to root-knot nematode and soybean mosaic virus in Nigeria. Fitopatol. Bras. 20: 190 - 193.

Kaplan, M. and Noe, J. P. 1993. Effects of chicken excrement amendments on Meloidogyne arenaria. Journal of Nematology 25: 71 - 77.

Rodriguez-Kabana, R. 1986. Organic and inorganic amendments to soil as nematode suppressants. Journal of Nematology 18: 129 - 135.

Sharma, S. K. Sharma., Sharma, G. L., and Baheti, B. L. 1997. Management of root-knot nematode Meloidogyne incognita on tomato through soil amendment with various composts. Indian Journal of Nematology 26: 263 - 265.

Verma, R. D., Mahendra, S., Samar, R., and Sharma, G. L. 1997. Effect of soil amendment against root-knot nematode Meloidogyne incognita on bottlegourd. Indian Journal of Nematology 27: 255 - 256

Whitehead, A.G. and Hemming, J.R. 1965. A comparison of some quantitative methods of extracting small vermiform nematodes from soil. Annals of Applied Biology 55:25-38.

Table 1: Physiochemical properties of the of the soil used for the experiments

\begin{tabular}{|c|c|c|}
\hline \multirow[t]{2}{*}{ Parameters } & \multicolumn{2}{|c|}{ Proportionate value } \\
\hline & Experiment I & Experiment II \\
\hline $\mathrm{pH}\left(\mathrm{H}_{2} \mathrm{O}\right)$ & 5.8 & 5.6 \\
\hline$\%$ Organic Carbon & 0.86 & 0.89 \\
\hline$\%$ Organic matter & 1.59 & 1.6 \\
\hline Total N (\%) & 0.16 & 0.19 \\
\hline Available P (\%) & 7.2 & 8.1 \\
\hline $\mathrm{Na} \mathrm{Cmol} / \mathrm{kg}$ & 0.66 & 0.63 \\
\hline \multicolumn{3}{|c|}{ Exchangeable bases (c mol kg-1) } \\
\hline $\mathrm{K}$ & 0.23 & 0.21 \\
\hline $\mathrm{Mg}$ & 0.82 & 0.79 \\
\hline $\mathrm{Ca}$ & 0.89 & 0.91 \\
\hline C.E.C & 2.79 & 2.81 \\
\hline \multicolumn{3}{|c|}{ Physical properties $\left(\mathrm{cmol} \mathrm{kg}^{-1}\right)$} \\
\hline Silt (\%) & 13 & 12.92 \\
\hline Clay (\%) & 6.19 & 6.21 \\
\hline Sand $(\%)$ & 89.01 & 89.07 \\
\hline Textural class & Sandy loam & Sandy loam \\
\hline
\end{tabular}

Table 2: Macro nutrient constituents of the organic fertilizers used for the study

\begin{tabular}{lccc}
\hline Organic Fertiliser & Nitrogen (\%) & Phosphorus (\%) & Potassium (\%) \\
\hline Sunshine Fertiliser & 3.50 & 1.00 & 1.20 \\
IAR\&T Fertiliser & 1.28 & 0.96 & 0.36 \\
Neem Fertiliser & 7.00 & 7.00 & 6.00 \\
\hline
\end{tabular}


Table 3: Effect of three novel organic fertilizers on growth parameters of nematodeMeloidogyne incognita-infected TGx 1019-2EN soybean variety

\begin{tabular}{|c|c|c|c|c|}
\hline Treatment & $\begin{array}{c}\text { Plant Height (cm) } \\
\text { four weeks after } \\
\text { inoculation }\end{array}$ & $\begin{array}{l}\text { Plant Height } \\
\text { (cm) eight weeks } \\
\text { after inoculation }\end{array}$ & $\begin{array}{c}\text { Stem girth (cm) } \\
\text { four weeks after } \\
\text { inoculation }\end{array}$ & $\begin{array}{c}\text { Stem girth }(\mathbf{c m}) \\
\text { eight weeks } \\
\text { after inoculation }\end{array}$ \\
\hline \multicolumn{5}{|c|}{ Experiment I (2008) } \\
\hline Control & 30.42 & 62.80 & 0.48 & 0.58 \\
\hline $\begin{array}{l}\text { Sunshine } \\
\text { Fertiliser }\end{array}$ & 66.90 & 103.00 & 0.53 & 0.81 \\
\hline IAR\&T Fertiliser & 65.03 & 100.67 & 0.53 & 0.73 \\
\hline Neem Fertiliser & 28.60 & 77.25 & 0.36 & 0.64 \\
\hline Treatment mean & 47.74 & 85.98 & 0.48 & 0.69 \\
\hline LSD (0.05) & 20.80 & 39.23 & 0.10 & 0.17 \\
\hline \multicolumn{5}{|c|}{ Experiment II (2009) } \\
\hline Control & 34.13 & 52.31 & 0.45 & 0.60 \\
\hline $\begin{array}{l}\text { Sunshine } \\
\text { Fertiliser }\end{array}$ & 68.17 & 112.21 & 0.53 & 0.90 \\
\hline IAR\&T Fertiliser & 66.51 & 112.57 & 0.51 & 0.74 \\
\hline Neem Fertiliser & 32.53 & 71.31 & 0.37 & 0.71 \\
\hline Treatment mean & 50.34 & 87.10 & 0.47 & 0.74 \\
\hline LSD $(0.05)$ & 20.15 & 35.35 & 0.11 & 0.19 \\
\hline
\end{tabular}

Table 4: Effect of three novel organic fertilizers on nematode Meloidogyne incognita populations in TGX 1019-2EN soybean variety

\begin{tabular}{|c|c|c|c|c|c|}
\hline Treatment & $\begin{array}{l}\text { No. of } \\
\text { galls per } \\
\text { plant }\end{array}$ & $\begin{array}{c}\text { Meloidogyne } \\
\text { incognita eggs/J2 } \\
\text { populations } \\
\text { recovered per plant }\end{array}$ & $\begin{array}{c}\text { No. of } \\
\text { Meloidogyne } \\
\text { incognita } \\
\text { adults } \\
\text { recovered } \\
\text { from the soil } \\
\end{array}$ & $\begin{array}{c}\text { Final } \\
\text { population } \\
\text { of } \\
\text { Meloidogyne } \\
\text { incognita } \\
\text { per plant } \\
\end{array}$ & $\begin{array}{c}\text { Nematode } \\
\text { reproduction } \\
\text { Factor (Final } \\
\text { population/5000 }\end{array}$ \\
\hline & \multicolumn{5}{|c|}{ Experiment I (2008) } \\
\hline $\begin{array}{l}\text { Control } \\
\text { Sunshine } \\
\text { Fertiliser }\end{array}$ & $\begin{array}{c}85.53 \\
4.65\end{array}$ & $\begin{array}{c}6,781 \\
79\end{array}$ & $\begin{array}{c}471 \\
46\end{array}$ & $\begin{array}{c}7,252 \\
125\end{array}$ & $\begin{array}{l}1.45 \\
0.03\end{array}$ \\
\hline $\begin{array}{l}\text { IAR\&T } \\
\text { Fertiliser }\end{array}$ & 5.41 & 81 & 35 & 116 & 0.02 \\
\hline $\begin{array}{l}\text { Neem } \\
\text { Fertiliser }\end{array}$ & 1.21 & 35 & 12 & 47 & 0.01 \\
\hline $\begin{array}{l}\text { Treatment } \\
\text { mean }\end{array}$ & 24.2 & 1,744 & 141 & 1,885 & 0.38 \\
\hline \multirow[t]{2}{*}{ LSD (0.05) } & 28.11 & $2,901.5$ & 190.1 & 3,207 & 0.61 \\
\hline & \multicolumn{5}{|c|}{ Experiment II (2009) } \\
\hline Control & 78.21 & 5,509 & 511 & 6,020 & 1.20 \\
\hline $\begin{array}{l}\text { Sunshine } \\
\text { Fertiliser }\end{array}$ & 5.34 & 73 & 35 & 108 & 0.02 \\
\hline $\begin{array}{l}\text { IAR\&T } \\
\text { Fertiliser }\end{array}$ & 5.93 & 91 & 41 & 132 & 0.03 \\
\hline $\begin{array}{l}\text { Neem } \\
\text { Fertiliser }\end{array}$ & 1.65 & 37 & 15 & 52 & 0.01 \\
\hline $\begin{array}{l}\text { Treatment } \\
\text { mean }\end{array}$ & 22.78 & $1,427.5$ & 150.5 & 1,578 & 0.32 \\
\hline LSD (0.05) & 27.22 & $2,115.8$ & 193.3 & 2,998 & 0.05 \\
\hline
\end{tabular}


Table 5: Effect of three novel organic fertilizers on yield components of soybean variety inoculated with Meloidogyne incognita

\begin{tabular}{|c|c|c|c|c|c|}
\hline Treatment & $\begin{array}{c}\text { No. of } \\
\text { branches per } \\
\text { plant }\end{array}$ & $\begin{array}{l}\text { No. of pods } \\
\text { per plant }\end{array}$ & $\begin{array}{c}\text { No. of seeds } \\
\text { per plant }\end{array}$ & $\begin{array}{l}\text { Pod weight } \\
\text { (g/plant ) }\end{array}$ & $\begin{array}{l}\text { Seed weight } \\
\text { (g/plant) }\end{array}$ \\
\hline & \multicolumn{5}{|c|}{ Experiment I (2008) } \\
\hline Control & 3 & 22 & 42 & 8.18 & 5.11 \\
\hline Sunshine & 3 & 41 & 69 & 16.82 & 10.06 \\
\hline $\begin{array}{l}\text { IAR\&T } \\
\text { Fertiliser }\end{array}$ & 3 & 39 & 71 & 15.74 & 10.20 \\
\hline $\begin{array}{l}\text { Neem } \\
\text { Fertiliser }\end{array}$ & 1 & 39 & 72 & 15.52 & 9.50 \\
\hline $\begin{array}{l}\text { Treatment } \\
\text { mean }\end{array}$ & 2.50 & 35.25 & 63.50 & 14.07 & 8.72 \\
\hline \multirow[t]{2}{*}{ LSD (0.05) } & 2 & 12 & 26 & 6.40 & 1.05 \\
\hline & \multicolumn{5}{|c|}{ Experiment II (2009) } \\
\hline Control & 2 & 21 & 42 & 7.14 & 6.81 \\
\hline $\begin{array}{l}\text { Sunshine } \\
\text { Fertiliser }\end{array}$ & 3 & 44 & 87 & 14.45 & 10.12 \\
\hline $\begin{array}{l}\text { IAR\&T } \\
\text { Fertiliser }\end{array}$ & 3 & 41 & 85 & 14.53 & 10.17 \\
\hline $\begin{array}{l}\text { Neem } \\
\text { Fertiliser }\end{array}$ & 2 & 38 & 71 & 8.52 & 9.51 \\
\hline $\begin{array}{l}\text { Treatment } \\
\text { mean }\end{array}$ & 2.50 & 36 & 71.25 & 11.16 & 9.15 \\
\hline LSD (0.05) & 2 & 13 & 23 & 6.13 & 1.19 \\
\hline
\end{tabular}


Table 6: Correlation among growth indices of Meloidogyne incognita-inoculated TGx 10192EN soybean variety

\begin{tabular}{|c|c|c|c|c|c|c|c|c|c|c|c|}
\hline $\begin{array}{l}\text { Paramete } \\
\mathrm{r}\end{array}$ & $\begin{array}{l}\text { Plan } \\
\text { t ht } \\
\text { (cm) }\end{array}$ & $\begin{array}{c}\text { Ste } \\
\text { m } \\
\text { Girt } \\
\text { h } \\
\text { (cm }\end{array}$ & $\begin{array}{l}\text { Gall } \\
\text { No. }\end{array}$ & $\begin{array}{l}\text { Eggs/J } \\
\qquad\end{array}$ & $\begin{array}{c}\text { Soil } \\
\text { Populatio } \\
n\end{array}$ & $\begin{array}{c}\text { Final } \\
\text { Populatio } \\
\mathbf{n}\end{array}$ & $\begin{array}{l}\text { RFacto } \\
\mathbf{r}\end{array}$ & $\begin{array}{l}\text { Pod } \\
\text { No. }\end{array}$ & $\begin{array}{c}\text { Seed } \\
\text { No. }\end{array}$ & $\begin{array}{c}\text { Pod } \\
\text { wt }\end{array}$ & $\begin{array}{l}\text { See } \\
d \text { wt }\end{array}$ \\
\hline
\end{tabular}

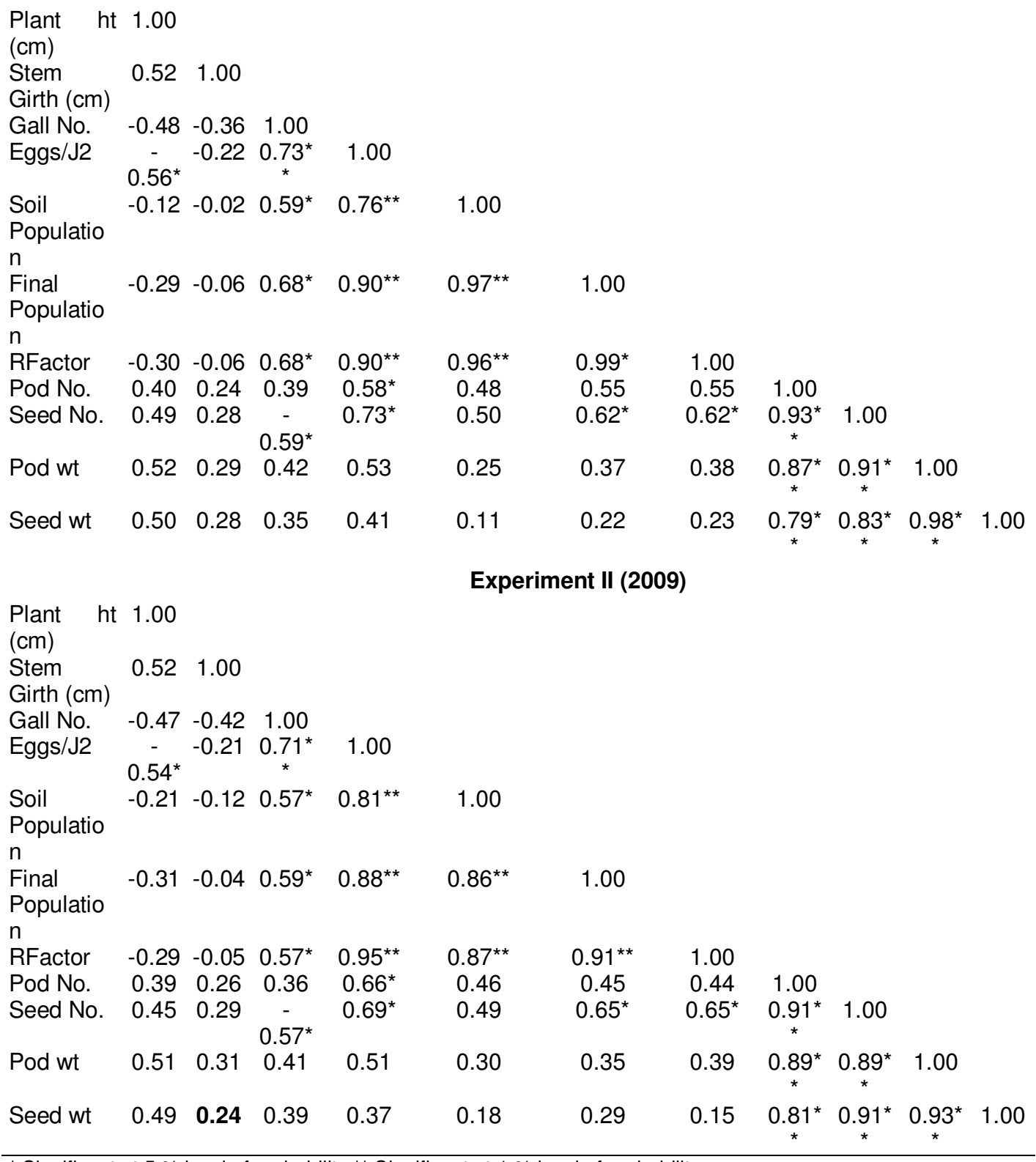

${ }^{*}$ Significant at $5 \%$ level of probability ${ }^{* *}$ Significant at $1 \%$ level of probability 